\title{
Diet Compliance Analysis Towards Blood Sugar Levels For Diabetes Mellitus Patients
}

\author{
Septi Dwi Rahmawati, Atik Setiawan Wahyuningsih, Eva Agustina Yalestyarini ${ }^{1}$ \\ ${ }^{I}$ STIKes Surya Mitra Husada, Kediri, East Java, Indonesia \\ Corresponding author : atiksetiawan9@gmail.com
}

\begin{abstract}
Background: People with diabetes mellitus are increasing in number. Controlling blood sugar levels is an action that must be taken to get normal and stable blood sugar levels. Self-control takes precedence over treatment. Compliance with diet is one of the important things in controlling blood sugar levels. Raflesia Room as one of the internal medicine inpatients in $\mathrm{dr}$. SoedomoTrenggalek, received inpatient care for the majority of diabetes mellitus patients.

Purpose : The purpose of this study was to analyze the relationship between diet adherence and blood sugar levels in people with diabetes mellitus.

Methods : The research design used descriptive analytic with cross sectional approach. The population in this study were patients with diabetes mellitus in the Raflesia room of Dr. SoedomoTrenggalek Hospital in January 2017 with 30 patients. With a simple random sampling technique so that 29 samples were obtained.

Result : The results showed that almost all respondents, namely $25(86 \%)$ respondents, had abnormal blood sugar levels. Almost all respondents, 23 (79\%) did not comply with the diet. Chi square test results obtained 0.004 which means there is a relationship between dietary compliance with blood sugar levels of diabetes mellitus patients in Raflesia room Dr. Soedomo Hospital Trenggalek in 2017.

Conclusion : Old age is an age that is susceptible to a decrease in body function, especially hormonal causes of decreased pancreatic function resulting in a decrease in insulin sensitivity which causes high blood sugar levels. The level of education has an important role in diet compliance where patients are required to understand 3J "Types, Amounts and Schedules" so that the lower level of education causes lower diet compliance. Disobedience to diets causes sufferers to consume irregular foods which cause a pile of glucose and blood so that hyperglycemia occurs.
\end{abstract}

Keywords : Diabetes Mellitus, Blood Sugar Levels, Dietary Compliance

Received July, 25, 2018; Revised August 24, 2018; Accepted September 14, 2018

How to Cite: Rahmawati, S., Wahyuningsih, A., Yalestyarini, E. (2018). Diet Compliance Analysis Towards Blood Sugar Levels For Diabetes Mellitus Patients. Journal Of Nursing Practice, 2(1), 73-79. https://doi.org/10.30994/jnp.v2i1.46 


\section{BACKGROUND}

Diabetes mellitus (DM) is a cause of high mortality due to the resulting cardiovascular disease. Patients with diabetes mellitus have 2-3 times higher risk than nonDM populations (Siregar, 2010). Diabetes mellitus (DM) is a chronic syndrome of metabolic disorders of carbohydrates, proteins, and fats due to insufficient insulin secretion or insulin resistance in tissues (Dorland, 2002). According to Riyadi\&Sukarmin (2008) there are several factors that cause an increase in blood sugar levels, namely genetic factors, age, stress, wrong diet and obesity.

Raflesia Room is an internal medicine inpatient room at RSUD $\mathrm{dr}$. SoedomoTrenggalek. Patients who were hospitalized in the raphlesia room were mostly diabetic mellitus. Patients with diabetes mellitus who are hospitalized due to problems with an increase in uncontrolled blood sugar.

The latest data from the (International Diabetes Federation, 2018) at the Diabetes Comolications Congress shows that currently the complications of DM lead to 425 million adults and will increase to 629 million in 2045. World Pratiwi, 2007 included data from the Health Organization (WHO) predicts the increase in the number of people with diabetes mellitus in Indonesia from 8.4 million in 2000 to around 21.3 million in 2030, even Indonesia ranks fourth in the world as the largest number of people with diabetes mellitus after India, China and America (as cited in Aini et al., 2012).

(KOMINFO, 2015) Based on data from Basic Health Research (Riskesdas) in Indonesia there are 10 million people with diabetes, and 17.9 million people at risk of developing this disease. While East Java Province entered the top 10 prevalence of diabetics throughout Indonesia or ranked ninth with a prevalence of 6.8. Monthly report in the Raflesia room of RSUD dr. Soedomo Trenggalek, the number of patients with diabetes mellitus who were treated in October to December 2016 was 72 patients. Based on the results of the diet obedience interview on 10 patients, 6 people were obedient and 3 people were not compliant.

Plasma glucose levels are determined at a time by the balance between the amount of glucose entering the bloodstream and the amount that leaves it. Therefore, the main determinant of input is from diet, the rate of entry into muscle cells, adipose tissue, and other organs, and liver glucostatic activity. Five percent of glucose consumed is converted directly into glycogen in the liver, and $30-40 \%$ is converted to fat. The rest is metabolized in muscles and other tissues. During fasting, liver glycogen is broken down from the liver to increase blood glucose levels. If there is a longer fasting, the liver glycogen is depleted and glycogenogenesis occurs from amino acids and glycerol in the liver (Ganong, 2010). So that to keep controlling the sugar levels diet compliance becomes one of the important elements to control sugar levels. But in reality not all people with diabetes mellitus are able to obey their diet. Disobedience of patients in managing diabetes mellitus will have a very large negative impact including increased health costs and diabetes complications (Aini et al., 2012).

From the description above the author will conduct research on the relationship of blood sugar levels with diet adherence in patients with diabetes mellitus in the Raflesia room of RSUD dr. SoedomoTrenggalek.

\section{OBJECTIVE}

The purpose of this study was to analyze the relationship between diet adherence and blood sugar levels in people with diabetes mellitus. 


\section{METHODS}

The research design used in this study is descriptive analytical method and cross sectional research type. The population in this study were all DM patients in the raphlesia room in RSUD Dr. Trenggalek in January 2017, totaling 30 patients with simple random sampling obtained 29 respondents. The statistical test used was Chi Square. The measuring instrument used to measure blood sugar levels using a glumometer to determine normal levels and abnormal blood sugar levels. Diet compliance measuring tool uses a questionnaire to identify compliance and non-compliance.

\section{RESULTS}

a. Characteristics of respondents age

Table 1. Age characteristics of DM patients in the Raflesia Room of RSUD dr. Soedomo Trenggalek dated April 5 to April 182017

\begin{tabular}{lcc}
\hline Characteristics & Amount & Percentage \\
\hline$\leq 20$ years old & 0 & 0 \\
21-25 years old & 0 & 0 \\
26-35 years old & 2 & 6 \\
$>35$ years old & 27 & 93 \\
\hline Totals & 29 & 100 \\
\hline
\end{tabular}

Primary source : 2017

From Table 1 shows that the majority of respondents aged $>35$ years were 27 respondents $(93 \%)$.

b. Characteristics of respondents based on gender

Table 2. Sex characteristics of DM patients in the Raflesia Room of RSUD dr. Soedomo Trenggalek dated April 5 to April 182017

\begin{tabular}{lcc}
\hline Characteristics & Amount & Percentage \\
\hline Laki-laki & 17 & 58 \\
Perempuan & 12 & 42 \\
\hline Totals & 29 & 100 \\
\hline Prat & &
\end{tabular}

Primary Source : 2017

Based on Table. 2 shows that more than some respondents were male as many as 17 respondents $(58 \%)$.

c. Characteristics of respondents based on education level

Table 3. Characteristics of education level of DM patients in the Raflesia Room of

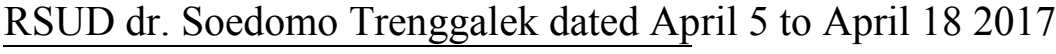

\begin{tabular}{lcc}
\hline Characteristics & Amount & Percentage \\
\hline SD & 3 & 10 \\
SMP & 9 & 32 \\
SMU & 17 & 58 \\
PT & 0 & 0 \\
\hline Totals & 29 & 100 \\
\hline Primary source $: 2017$ &
\end{tabular}

Primary source : 2017

From Table 3 shows that more than half of respondents with high school education were 17 respondents $(58 \%)$..

d. Characteristics of respondents based on job

Table 4. Job characteristics of DM patients in the Raflesia Room of RSUD dr. SoedomoTrenggalek dated April 5 to April 182017 


\begin{tabular}{lcc}
\hline Characteristics & Amount & Percentage \\
\hline Unemploy & 5 & 17 \\
Farmer & 7 & 25 \\
Entrepreneur & 17 & 58 \\
Civils/self employ & 0 & 0 \\
\hline Jumlah & 29 & 100 \\
\hline
\end{tabular}

Primary source : 2017

Based on Table 4, showed that more than some respondents were entrepreneur as many as 17 respondents $(58 \%)$

e. Blood sugar levels

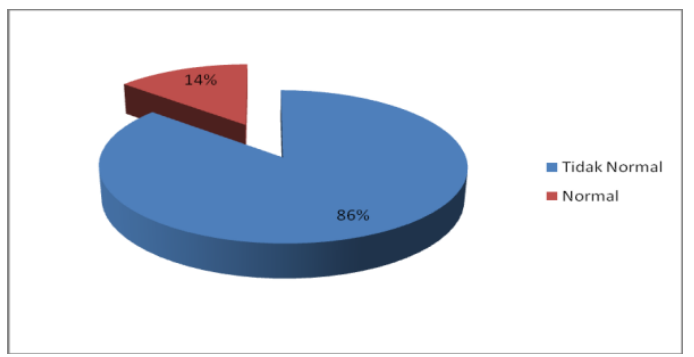

Based on diagram 1 shows that almost all respondents have abnormal sugar levels, namely there are $25(86 \%)$ of the total 29 respondents

\section{f. Compliance With Diet}

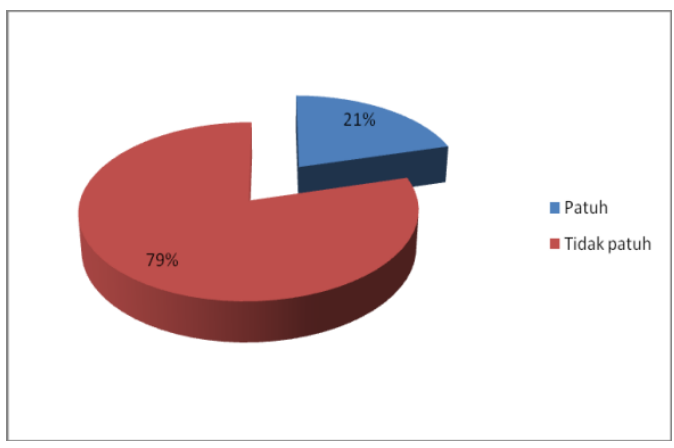

Based on diagram 2 shows that almost all respondents did not comply with the diit, namely 23 respondents (79\%) of the total respondents 29 respondents

g. Tabulation tabulation of diet compliance with blood sugar levels

Table 5 cross tabulation of sugar content with diit adherence to diabetes mellitus patients in the Raflesia room of RSUD dr. SoedomoTrenggalek dated April 5 to April 182017

\begin{tabular}{ccccc}
\hline & Comply Diet & Uncomplyed diet & Total & ValueP \\
\cline { 2 - 3 } Normal Blood sugar & 4 & 23 & 27 & \\
& $14.8 \%$ & $79.3 \%$ & $93.1 \%$ & \\
Abnormal Blood Sugar & 2 & 0 & 2 & 0.004 \\
& $6.9 \%$ & $0 \%$ & $6.9 \%$ & \\
\hline TOTAL & 6 & 23 & 29 & \\
& $20.6 \%$ & $79.3 \%$ & 100 & \\
\hline
\end{tabular}

Based on Table 5 shows almost all respondents had sugar levels in the abnormal category and did not comply with diit as many as 23 respondents $(79.3 \%)$.

\section{DISCUSSION}

a Blood sugar levels 
Based on diagram 1, it is known that almost all respondents had abnormal sugar levels, namely $25(86 \%)$ of the total 29 respondents and almost all respondents aged $>$ 35 years, as many as 27 respondents $(93 \%)$ of a total of 29 respondents.

Based on research conducted by Wahyuningsih\& Nusantara (2017) in the title of patients with DM with insomnia in terms of characteristics shows that diabetes mellitus is the most common in the elderly. Diabetes mellitus (DM) is a group of heterogeneous disorders characterized by increased levels of glucose in the blood or hyperglycemia. Glucose normally circulates in a certain amount in the blood. Glucose is formed in the liver from the food consumed. Insulin is a hormone produced by the pancreas, controlling glucose levels in the blood by regulating its production and storage (Smeltzer\& Bare, 2002). Increased sugar levels can be influenced by age and stress, where humans generally experience a physiological decline that dramatically decreases rapidly after age 40 . This decrease will be at risk for decreasing the endocrine function of the pancreas to produce insulin.

Elderly age is the age at which respondents experience a decline in all tissue functions, disrupted hormone production including decreased insulin production and decreased long-term memory that causes uncontrolled respondents in medication adherence. Besides diabetes mellitus is a type of disease that can only be controlled, but can not be cured, so suffering from long-term disease can cause the boredom of respondents so often do not pay attention to the condition of blood sugar conditions, respondents began to not care about the disease so that abnormal blood sugar increases not give any influence to the respondent.

\section{b Compliance with diet}

Based on diagram 2, it is known that most of them do not comply with the diet, which is $79 \%$ of the total respondents of 29 respondents.

Compliance is a behavior in keeping a recommendation on daily habits and can be scored with the research score. A compliance is influenced by the level of education, where education is a major basis in the success of prevention or treatment (Tjokroprawiro, 2002).

Based on Table 3 it is known that more than half of respondents with high school education were 17 respondents (58\%). This shows that $42 \%$ of other respondents still lack education, namely elementary and junior high school. This is consistent with the research conducted by Senuk et al., 2013 that education has a role to play in increasing compliance with the information provided.

In regulating the diet for people with diabetes mellitus, the principle is $3 \mathrm{~J}$, namely:

a) Amount

The amount of food consumed is adjusted to height, weight, type of activity, and age. You can calculate your calorie needs based on guidelines on daily calorie requirements.

b) Type

Food preparation for people with diabetes mellitus includes carbohydrates, proteins, fats, and fruits and vegetables. Nutritional needs must be fulfilled with the right menu so as not to raise blood sugar.

c) Schedule

That is a fixed meal time including breakfast, lunch, dinner, and a snack. 
Compliance is an order in carrying out actions that are in line with the objectives to be achieved. Understanding the purpose of treatment in patients with diabetes mellitus is influenced by maturity in thinking. Compliance with the DM treatment diet requires adequate education so that the patient is able to control the desire to consume the desired food but must be avoided. Education is one of the milestones of knowledge to take real action.

With education that is insufficient for patients with DM, they will find it difficult to determine $3 \mathrm{~J}$, namely the exact number, the right type and the right schedule. DM sufferers are required to know how many calories must be consumed every meal and what time or time the patient is allowed to consume food. This condition requires DM sufferers to process their knowledge and be shown clearly in the form of compliance with DM treatment die.

So that if education is insufficient it will tend to look less obedient in treatment and have an impact on deviant behavior with goals.

\section{c Blood sugar levels and dietary compliance}

Based on the results of the statistical test in table 1, the results of the statistical value (p-value) chi square obtained Sig (2-tailed) is equal to $=0.004$ means $<$ of the value of $\alpha$ (alpha) $=0.05$. Then $\mathrm{H} 0$ is rejected and $\mathrm{H} 1$ is accepted which means that there is a correlation between sugar levels and diet adherence in patients with diabetes mellitus in the Raflesia room of RSUD dr. SoedomoTrenggalek 2017.

Wahyuningsih\&Utami (2017) stated in his study that patients who were less able to control food consumption caused blood sugar levels to rise despite regular exercise, so it was important for DM sufferers to comply with the 4 pillars of DM treatment according to the PERKENI program. Health research journal results, about the relationship of blood sugar levels with diet compliance (Reizel et al, 2003) states that there is a significant relationship between blood sugar levels with diet adherence in patients with diabetes mellitus associated with the theory of blood sugar levels that blood sugar levels are influenced one by diet compliance. Stating that by increasing one's adherence it will cause the patient to be careful in his diet, so that blood sugar levels can be controlled.

Diabetes mellitus is a group of heterogeneous disorders characterized by increased levels of glucose in the blood or hyperglycemia. Glucose normally circulates in a certain amount in the blood. Glucose is formed in the liver from the food consumed. Insulin, which is a hormone produced by the pancreas, controls the level of glucose in the blood by regulating its production and storage (Smeltzer\& Bare, 2002).

Referring to the results of the research above that sugar levels have a relationship with diet compliance, it is in accordance with the theory that in diet compliance which is related to the amount of food consumed, the type of food that is appropriate and the right schedule too, diet compliance becomes very important. Compliance is influenced by several things, including work, due to the work of the respondent as an entrepreneur. This type of work such as self-employment makes respondents often forget about and become disobedient with their diet because of the many activities, then causing blood sugar to increase. Entrepreneurial work also deals with many people, which allows many supporters who can remind respondents of their compliance.

Social support in the form of emotional support from other family members and friends can help reduce anxiety, they can eliminate the temptation to non-compliance, 
and they often become support groups to achieve compliance. As a supporter, the need for people with diabetes mellitus to always re-control their illness so they can always control their blood sugar levels, so they don't fall into poor health. In addition, the age of respondents is a factor that influences respondents. The respondent's age was almost entirely more than 35 years, where the age showed a decrease in organ function in the body, decreased long-term memory and the length of time to suffer from diabetes mellitus made the respondents reluctant to return to the diet. The thing that is most likely to be done by patients with diabetes mellitus is only to reduce drinking and sweet foods, but often forget the schedule and the amount that must be consumed. Thus blood sugar levels are closely related to diet adherence to diabetes mellitus patients.

\section{CONCLUSION}

Almost all respondents have abnormal sugar levels, and most of them do not obey their diit. There is a correlation between sugar levels and diit adherence in diabetic patients in the Raflesia room of RSUD dr. SoedomoTrenggalek 2017.

\section{REFERENCES}

Arikunto, Suharsimi. (2002). ProsedurPenelitian. Jakarta: RinekaCipta

Basuki, E (2005). Teknik Penyuluhan Diabetes Melitus. Penatalaksanaan Diabetes Melitus Terpadu. Jakarta :FKUI.

Guntur. (2006). Faktor yang berhubungan dengan pengendalian kadar gula darah pada penderita diabetes mellitus diperkotaan Indonesia. Badan penelitian dan pengembangan DepKes RI. Jakarta

Depkes. (2011). Prevalensi Penyakit Diabetes Melitus. Diakses: 20 Januari 2015. Dari: http://www.depkes.go.id/download.publikasi ditjen

Guntur. (2009). Penatalaksanaan Diabetes Melitus Terpadu. Edisi II Cetakan

Ke-5. Jakarta: Fakultas Kedokteran UI.

Guyton, A.C., dan Hall, J.E. (2008). Buku Ajar Fisiologi Kedokteran. Edisi 11. Jakarta: EGC

KOMINFO. (2015). Masih Tinggi Prevalensi Diabetes di JaTim tahun 2015

Pratiwi. (2013). Kiat perawatan Diabetes Melitus. htpp://www. sehattanpa diet"

Purwanto. (2012). Mencegah Komplikasi Penyakit Kencing Manis. Diakses 20 Januari 2015. Dari: http://www.sinarharapan.konsultasi/html

Riwidikdo. (2007). Statistik Kesehatan. Jakarta: Mitra Cendikia

Smeltzer dan Bare. (2008). Buku Ajar Keperawatan Medikal Bedah Brunner dan Suddarth (Ed.8, Vol. 1,2), Alih bahasa oleh Agung Waluyo (dkk), EGC, Jakarta.

Sugiyono. (2011). Statistik Untuk Penelitian. Bandung: CV ALFABETA

Soekarmin, riyadi, dkk. (2002). Dari Empat Sehat Lima Sempurna KePedoman Gizi Seimbang dan buku Hidup Sehat Gizi Seimbang dalam Siklus Kehidupan Manusia. Prima media Pustaka. Jakarta

Tim penyusun Depkes RI. (2005). Pharmautical Care Untuk Penyakit Diabetes Melitus. Jakarta :Dirjen Bina Kefarmasian dan Alat Kesehatan Depkes RI 